\title{
ARACHNOID GRANULATION AFFECTED BY SUBARACHNOID HEMORRHAGE
}

\author{
R.P. CHOPARD *, R.C. BRANCALHAO **, M.H. MIRANDA-NETO ***, \\ W. BIAZOTTO ***
}

\begin{abstract}
SUMMARY - The purpose of this study was to investigate using light microscopy the fibrocellular components of arachnoid granulations affected by mild and severe subarachnoid hemorrage. The erythrocytes were in the channels delimitated by collagenous and elastic bundles and arachnoid cells, showing their tortuous and intercommunicating row from the pedicle to the fibrous capsule. The core portion of the pedicle and the center represented a principal route to the bulk outflow of cerebrospinal fluid and erythrocytes. In the severe hemorrhage, the fibrocellular components are desorganized, increasing the extracellular channels. We could see arachnoid granulations without erythrocytes, which cells showed big round nucleous suggesting their transformation into phagocytic cells.
\end{abstract}

KEY WORDS: arachnoid granulation, subarachnoid hemorrhage, cerebrospinal fluid.

\begin{abstract}
Estudo dos componentes fibrosos das granulacões aracnóides na presença de hemorragia subaracnóide.

RESUMO - Por microscopia óptica foram estudados os componentes fibrosos das granulações aracnóides de indivíduos acometidos por hemorragia subaracnóide de tipo moderado ou severo. Os eritrócitos estavam presentes nos canais delimitados por feixes de fibras elásticas, colágenas e céluias aracnóides. Os canais tortuosos e intercomunicantes eram observados desde o pediculo até a cápsula fibrosa da granulação aracnoide. O principal trajeto dos eritrócitos e do liquido céfalo-raquidiano ocorria no interior do pedículo e centro da granulação aracnóide. Na hemorragia severa, os componentes fibro-musculares estavam desorganizados e os canais extracelulares aumentados. A presença de células com grandes núcleos, observada no material hemorrágico, é sugestiva de transformações das céluias aracnóides em células fagocitárias, para promover a digestăo intracelular dos eritrócitos.
\end{abstract}

PALAVRAS-CHAVE: granulação aracnóide, hemorragia subaracnóide, líquido cefalorraquidiano.

Many authors have been studying the cerebrospinal fluid (CSF) transport through arachnoid granulation. Two hypotheses have gained special attention. The first accepts the existence of open channels of communication between subaracnoid space and superior sagittal sinus, across granulation, attributing to this structuce valvular function $1,6,7,10,15,16,19-21,25,27,29-31$. The second, denies the existence of open channels of communication between subarachnoid space and superior sagittal sinus and attributes a process of filtration for the CSF absorption 2,4,11,22-24,26,28. The possibilities of existence of both mechanisms of CSF transport are also accepted $8,9,12,13,18,32,33$.

Some authors use erythrocytes as a natural tracer of CSF in the granulation affected by subarachnoid hemorrhage. Some of them ${ }^{2-4,22-24}$ affirm that erythrocytes cross in an altered form for the venous system; others $1,17,25,29-31$ say that erythrocytes cross to unaltered form and some others say that erythrocytes do

\footnotetext{
* Departamento de Anatomia, Instituto de Ciências Biológicas (ICB), Universidade de São Paulo (USP); ** UNIOESTE, Cascavel, Paraná; *** Universidade Estadual de Maringá, Paraná. Aceite: 30-março-1993.

Dr. Renato P. Chopard - Departamento de Anatomia - Faculdade de Medicina, USP - Av. Dr. Arnaldo 455 - 01246-000 São Paulo SP - Brasil.
} 
not cross 11,14 to the venous system. The present study was undertaken to inves tigate the morphofunctional structure of human arachnoid granulation affected by severe and mild subarachnoid hemorrhage providing a comparative analysis, and also contributing for the information on the mechanism and functional value of these important anatomical structures.

\section{MATERIAL AND METHOD}

The material was obtained postmortem from 8 subjects of both sexes with age ranging from 20 to 60 years old. These subjects comprised 4 cases of small meningeal vessels rupture with mild subarachnoid hemorrhage noticed through CSF analysis, and 4 cases with rupture of aneurysms of basilar artery with severe subarachnoid hemorrhage. Following dissection the pieces were fixed in $10 \%$ formalin during 96 hours. Groups of granulation were removed for histological study, embedded in paraffin and serial vertical and horizontal sections were made at 7 and $20 \mu \mathrm{m}$ and stained with Azan and hematoxylin-eosin. The sections of the selected areas were examined with a Wild M 20 photomicroscope.

\section{RESULTS}

Fibrous components

In the material of the subjects with mild subarachnoid hemorrhage it was observed that there were erythrocytes inside collagenous meshwork (Fig. 1) in all extension of arachnoid granulation, particularly in the center (Fig. 2). In severe hemorrhage, the collagenous fibers in the core center of the granulation suffered desestructuration, increasing the space in the channels (Fig 3).

Cellular components

The arachnoid cells, with round and pavimentous nucleous, are on fibrous components and through their cytoplasmatic process form channels with erythrocytes inside organized in tortuous row in the core region of the pedicle and center. In this same material we can find granulation without erythrocytes, and we can see cells with big round nucleous (Fig. 4).

In severe hemorrhage the collagenous and elastic bundles, in the center of arachnoid granulation, suffer desestructuration widening the cannallicular space in the channels and reducing the density of fibrous components. We can see erythrocytes agglutination and the breaking of the continuity between nearby arachnoid cells.

\section{COMMHNTS}

\section{Fibrous components}

The presence of erythocytes inside collagenous network of the arachnoid granulation and fibrous capsule (figs. 1 and 2) allows detailed analysis of the

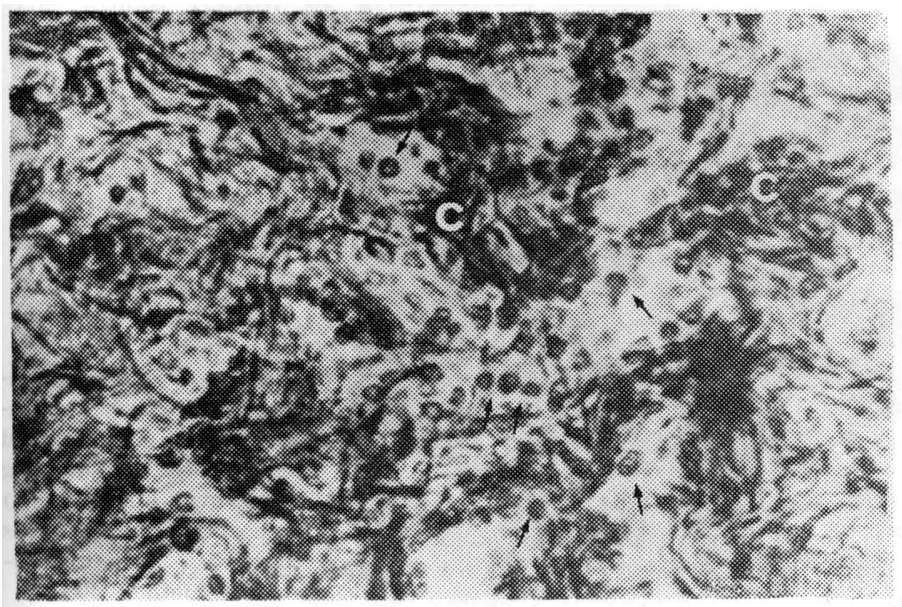

Fig. 1. Arachnoid granulation. Horizontal section, $20 \mu \mathrm{m}$, showing erythrocytes (arrow) inside collagenous meshwork (c) in the center of granulation. Azan's method $400 \times$. 


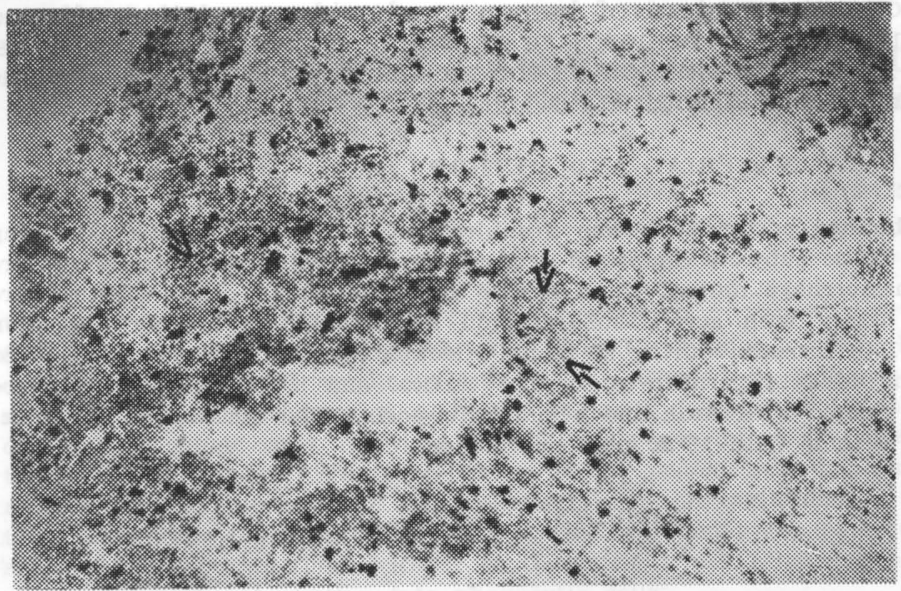

Fig. 2. Arachnoid granulation. Transverse (horizontal) section, $7 \mu \mathrm{m}$, subarachnoid hemorrhage, showing erythrocy tes (arrow) agglutination in the center of granulation. Hematoxilin-eosin's method $100 \times$.

Fig. 3. Arachnoid granulation. Vertical section, showing erythrocytes (arrow) in the center of granulation, with desestructuration of collagenous fibers (CP). Azan's method $100 \times$.
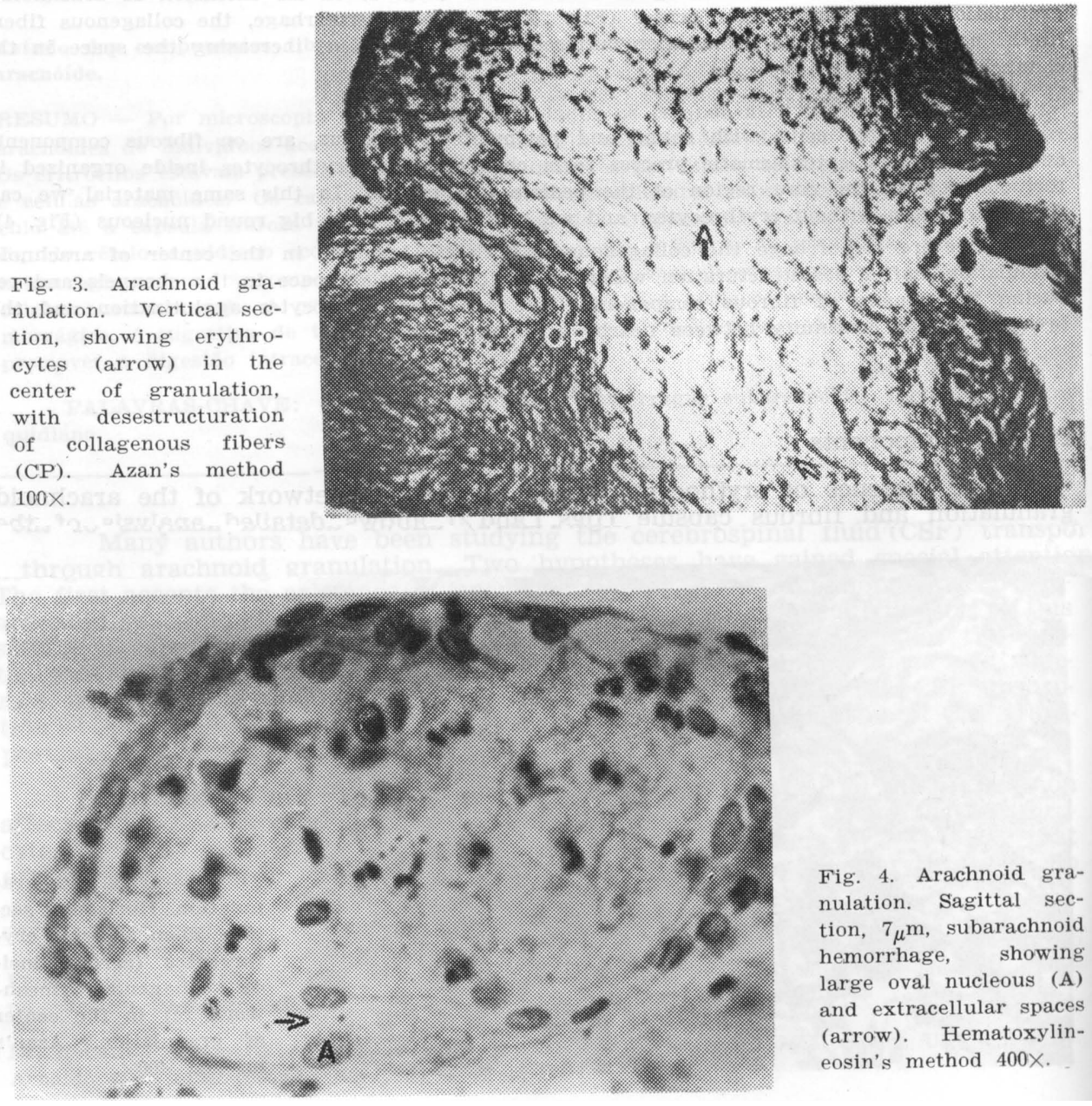

Fig. 4. Arachnoid granulation. Sagittal section, $7 \mu \mathrm{m}$, subarachnoid hemorrhage, showing large oval nucleous (A) and extracellular spaces (arrow). Hematoxylineosin's method $400 \times$. 
tortous channels existence between collagenous bundles and undoubtedly show the intercommunication of these channels from the pedicle to fibrous capsule; this condition reveals the permeability of these channels. According to the data our research provided this could lead erythrocytes direct for the superior sagittal sinus. It is possible that in the severe hemorrhage (fig. 3) the presence of great amount of erythrocytes provoke excessive increase of the CSF viscosity; this would difficult the absorption process according to Davson et al.10, causing elevation of subarachnoid space pressure with consequent desestructuration of collagenous bundles, agglutination and desintegration of erythrocytes, and it would block up the channels and interrupt the drainage. Perhaps, this situation was found by many authors $2-4,11,14,22-24$ that deny the passage of erythrocytes of subarachnoid space for the superior sagittal sinus.

In conformity with Miranda Neto et al.18, the association between collagenous and elastic bundles forms a dynamic organization that answers to different functional states. Under these conditions the distension and retraction of elastic bundles would provoke change in collagenous network, and this would limit the excessive extension of elastic bundles preventing its desestructuration.

In severe hemorrhage, the CSF viscosity and agglutination of erythrocytes would difficult the absorption process, causing elevation of pressure that results in excessive distension of elastic and collagenous bundles until their rupture and desestructuration; since the arachnoid cells are fibrous components, they pass through similar process.

\section{Cellular components}

Our results reveal the way traves by erythrocytes into extracellular space of arachnoid granulation, reaching the fusion region and to cluster in fibrous capsule. This is a strong indication of the passage of erythrocytes and CSF through the granulation reaching the venous system, in accord to other study reports $1,9,12,13,17,25,27,29-31,33$.

The presence of cells with large oval round nucleous observed in hemorrhage material (Fig.4) could be related to the transformation of arachnoid cells in phagocytic cells that promove the intracellular digestion of erythrocytes in arachnoid granulation 2-4,14,22-24. Nevertheless, we do not agree with authors that report this form as the only one for eliminating erythrocytes. We agree with Yamashima 33 , and therefore we believe that the phagocytose and direct passage of erythrocytes from arachnoid granulation to the superior sagittal sinus all together are responsible for CSF clearance. Another point is that the passage of erythrocytes by passive mechanism through extracellular space is an immediate mechanism that starts as soon as erythrocytes reach the granulation, while the transformation of arachnoid cells into phagocytic cells is a mechanism "a posteriorin that requires time for the cells transformation.

The great concentration of erythrocytes in the core region of pedicle and center of granulation (Fig. 4) would suggest a preferential route in direction to the apical region of granulation, reaching the fusion region and last to the venous system.

\section{Conclusions}

1. In the severe subarachnoid hemorrhage occurs agglutination of erythrocytes into arachnoid granulation, with consequent desestructuration of fibrocellular components.

2. The core region of pedicle and center of arachnoid granulation would represent a principal route of the bulk outflow of CSF and erythrocytes.

3. The disposition of erythrocytes in line into the granulation since pedicle until fibrous capsule shows an architecture compatible with the existence of continous channels, forming functional channels for exit of the CSF.

\section{REFERENCES}

1. Adams JE, Prawirohardjo S. Fate of red blood cells infected into cerebrospinal fluid pathways. Neurology 1959, 9:561-564.

2. Alksne JF, White LEJr. Electron-microscope study of the effect increased intracranial pressure on the arachnoid villus. J Neurosurg 1965, 22:481-488. 
3. Alksne JF, Richmond VA. Arachnoid villi after subarachnoid blood. J Neurophatol Exp Neurol 1971, 30:135.

4. Alksne JF, Lovings ET. The role of the arachnoid villus in the removal of red blood cells from the subarachnoid space: an electron microscope study in the dog. $J$ Neurosurg $1972,36: 192-200$.

5. Clark LG. On the pacchionian bodies. $J$ Anat 1920, 55:40-48.

6. Cunninghan DJ. Anatomia humana. Ed 8. Barcelona: Manuel Marin, 1949, Tomo 2.

7. Cushing $H$. Some experimental and clinical observations concerning the states of increased intra-cranial tension. Am J A Med Sci 1902, 124:375-400.

8. D'Avella D, Baroni A, Mingrino S. An electron microscope study of human arachnoid villi. Surg Neurol 1980, 14-41-47.

9. D'Avella D, Cicciarello R, Albiero F, Andriolo G. Scanning electron microscope study human arachnoid villi. J Neurosurg 1983, 59:620-626

10. Davson H, Hollingsworth G, Segal MB. The mechanism of drainage of the cerebrospinal fluid. Brain 1970, 93:665-678.

11. Ellington E, Margolis G. Block of arachnoid villi by subarachnoid hemorrhage. J Neurosurg 1969, 30:651-657.

12. Gomez DG, Potts DG, Deonarine V, Reilly KF. Effects of pressure gradient changes on the morphology of arachnoid villi and granuiations of the monkey. Lab Invest 1973, 28: 648-657.

13. Gomez DG, Potts DG, Deonarine V. Arachnoid granulations of the sheep. Arch Neurol $1974,30: 169-175$.

14. James AE, McComb JG, Christian J, Davson $H$. The effect of cerebrospinal fluid pressure on the size of drainage pathways. Neurology 1976, 26:659-662.

15. Jayatilaka ADP. Arachnoid granulation in sheep. $J$ Anat 1965, 99:315-327.

16. Jayatilaka ADP. An electron microscopic study of sheep arachnoid granulations. J Anat $1965,99: 635-649$.

17. Julow J, Ishii M, Iesnuvhi T. Arachnoid villi affected by subarachnoid pressure and hemorrhage: scanning electron microscopic study in the dog. Acta Neurochir 1979, 51:63-72.

18. Miranda-Neto MH, Biazotto W, Chopard RP, Lucas GA. Estudo micro-mesoscópico das granulações aracnóides humanas. Arq Neuropsiquiatr 1990, 48:151-155.

19. Potts DG, Deonarine $V$, Welton $W$. Perfusion studies of the cerebrospinal fluid absortive patways in the dog. Radiology 1972, 104:321-325.

20. Potts DG, Kenneth FR, Deonarine V. Morphology of the arachnoid villi and granulations. Radiology 1972, 105:333-341.

21. Potts DG, Deonarine V. Effect of positional changes and jugular veins compression on the pressure gradient across the arachnoid villi and granulations of the dog. $J$ Neurosurg 1973, $38: 722-728$.

22. Shabo AL, Maxwell DS. The morphology of the arachnoid villi: a light an electron microscopic study in the monkey. J Neurosurg 1968, 29:451-463.

23. Shabo AL, Maxwell DS. Electron microscopic observations on the fate of particulate matter in the cerebrospinal fluid. J Neurosurg 1968, 29:464-474.

24. Shabo AL, Abbott MM, Maxwell DS. The response of the arachnoid villus to an intracisternal injection of autogenous brain tissue: an electron microscopic study in the macaque monkey. J Neurosurg 1969, 19:724-734.

25. Sprong W. Disappearance of blood from cerebrospinal fluid in traumatic subarachnoid hemorrhage: ineffectiveness of repeated lumbar punctures. Surg Gynec Obst 1934, 58:705.

26. Tripathi $R$. Tracing the bulk outflow rout of cerebrospinal fluid by transmission and scanning electron microscopy. Brain Res 1974, 80:503-506.

27. Upton ML, Weller RD, Path FRC. The morphology of cerebrospinal fluid drainage pathways in human arachnoid granulations. $J$ Neurosurg 1985, 63:867-875.

28. Weed LH. Studies on the cerebrospinal fluid: II. The theories of drainage of cerebrospinal tluid with an analysis of the methods of investigation, $J$ Med Res 1914, 31:21-49.

29. Welch $K$, Friedman $V$. The relation between the structure of arachnoid an their functions. Surg Forum 1959, 10:767-769.

30. Welch $\mathrm{K}$, Friedman V. The cerebrospinal fluid valves. Brain 1960, 83:454-469.

31. Welch K, Pollay M. Perfusion of particles through arachnoid villi of the monkey. Am J Physial 1961, 201:651-654.

32. Yamashima T. Ultrastructural study of the final cerebrospinal fluid pathway in human arachnoid villi. Brain Res 1986, 384:68-76.

33. Yamashima $T$. Functional ultrastructure of cerebrospinal fluid drainage channels in human arachnoid villi. Neurosurgery 1988, 22:633-641. 